\title{
Bir İdeal, Bir Amerikan Başkanı ve Onun Başarısızlı̆̆ı: Başkan Wilson ve Milletler Cemiyeti
}

\author{
Dr. M. Vedat GÜRBÜZ*
}

\section{ÖZET}

Amerikan başkanı Woodrow Wilson Milletler Cemiyeti teşkilatının kurulmasına önderlik yapmıştır. Birinci Dünya Savaşı sonrası Amerikan menfaatlerine uygun bir dünya düzeni kurulması için ortaya çıkan Milletler Cemiyeti fikri, aynı zamanda dünya barışını korumak için etkili bir yol olarak tasarlanmıştır. Girişimiyle teşkilatın kurulmasında başarılı olan Wilson, ne var ki, Avrupa'da gösterdiği başarıyı ülkesinde gösteremeyerek, Amerika Birleşik Devletleri'nin bu teşkilat dışında kalmasını engelleyememiştir.

\section{ABSTRACT}

American president Woodrow Wilson led the establishment of the League of the Nations organization. Wilson thought that the establishment of the League would help for the establishment of the new world political order suitable for American national interests. The establishment of this organization was also speculated by world public as an important political instrument to keep world peace. Despite, Wilson succeeded for the establishment of the organization, but he failed to bring the United States into the League of Nations.

\section{GİRIŞ}

Tarih boyunca milletler ve ülkeler arasındaki güç mücadelesi eksik olmamıştır. Modern zamanlardaki güç mücadeleleri, Avrupa devletlerinin sanayileşmeye başlamaları ve sömürgeler kurmaları sonucu, dünya genelinde Avrupa menşeli yıkımlara ve büyük savaşlara sebebiyet vermiştir. Bir yandan dünyanın materyal ve insan kaynaklarını sömürmeye çalışan Avrupa'nın büyük güçleri, bir yandan da kendi aralarında şiddetli bir

\footnotetext{
• Kahramanmaraş Sütçü İmam Üniversitesi, Fen-Edebiyat Fakültesi.
} 
rekabete girișerek, birbirlerine karşı tehdit oluşturmaya başlamıșlardır. Rekabetten doğan kamplaşmalar, birbirine düşman siyasi ittifaklara dönüşerek nihayetinde I. Dünya Savaşı gibi büyük bir felakete zemin hazırlamı̧tır.

I. Dünya Savaşı ile Avrupa'daki çıkar hesaplarının ve kutuplaşmaların insanlık üzerinde nasıl bir tahribat yaratabileceği tüm dehşetiyle gözler önüne serilmiştir. Savaşın Avrupa'daki etkisi doğal olarak dünyanın diğer bölgelerindeki etkisinden daha fazla olmuştur. Savaş sonrasında Almanya 39 milyar dolar maddi zarara uğradı ve 1.600 .000 vatandaşını yitirdi. Savaş İngiltere ve sömürgelerinde 38 milyar dolar maddi hasara ve 900.000 civarında insan kaybına yol açtı. Savaş sonucu Rusya'da maddi zarar 18 milyar dolar ve insan kaybı 1.600.000, Fransa'da maddi zarar 26 milyar dolar ve insan kayb1 1.385.000, Avusturya-Macaristan İmparatorluğunda 21 milyar dolar maddi zarar ve 800.000 insan kaybı, İtalya'da 13 milyar dolar maddi zarar ve 364.000 insan kaybı meydana gelmiştir. Savaş Amerika Birleşik Devletleri'nde de önemli bir zarara yol açmış ve savaş sonucu ABD 22 milyar dolar maddi zarar görmüş ve 50.300 insanını kaybetmiştir. Toplamda ise I. Dünya Savaşında hayatlarını kaybeden insanların sayısı 7,58 milyon civarında olmuştur. ${ }^{1}$

Dünya o güne kadar I. Dünya Savaşı gibi bir felaket görmemişti. Asıl tehlikeli olanı ise bu felaketin son olmadığı, bunun top yekun savaşların sadece bir başlangıcı olduğu düşüncesinin dünya liderleri ve kamuoyları tarafından paylaşılmasıydı. Öyleyse yol yakınken bu felaketten ders alınmalı ve böylesi bir tehlikeye tekrardan yakalanmamak için önlemler alınmalı idi.

Avrupa siyasetine uzak duran ve politik ajandası Avrupa'dan farklı olan $\mathrm{ABD}$, içine kapanık bir dış politika izlemesine rağmen Başkan Wilson liderliğinde istikbaldeki çatı̧̧maları önleyecek yeni bir dünya düzeninin kurulması için politik inisiyatif başlattı. Başkan Wilson gerek taşıdığı kişisel ve romantik duygular ve gerekse Amerika'nın çıkarlarıyla uyuştuğu için daha barışçıl bir dünya ve Avrupa'nın korumacı geleneğine karşın dünya ticaretinde daha fazla serbestlik içeren yeni bir uluslararası rejim düşledi. Gerçekte ne Avrupa alı̧̧kanlıklarını terk etmek niyetini taşıyordu ne de Amerikan devleti ve kamuoyu Başkan Wilson'un kurucusu olmaya çalıştığı bu tür bir dış politika değişikliğine henüz kendisini hazır hissediyordu. Avrupa devletleri ise taze güç olarak Amerika'yı kendi yanlarına çekmeye ve Wilson'un açılımlarını daha ziyade çıkarları için kullanmaya çalışıyorlardı.

${ }^{1}$ Thomas G. Paterson, Dennis Merril, Major Problems in American Foreign Relations Since 1914, D.C. Heath and Company, Lexington, Massachusetts, 1995, ss. 43-44. 


\section{Başkan Wilson ve Milletler Cemiyeti'nin Kuruluş Faaliyetleri}

I. Dünya Savaşının sonlarında Almanya'nın yenilgiyi kabul ederek ateşkes istemesi üzerine, 18 Ocak 1919'da Paris yakınlarındaki Versailles sarayında barış görüşmeleri başladı. Bu görüşmelerde Wilson Amerikan heyetine başkanlık yaptı. Woodrow Wilson Atlantik'i geçerek Avrupa'yı ziyaret eden ikinci Amerikan başkanı idi. Aylar süren pazarlıklar Wilson'da bir hayal kırıklığı ve klasik büyük güç politikalarına entegre olmak hususunda isteksizlik yaratmıştı. Ancak yaz aylarında Wilson Avrupa'nın sıkıcı pazarlıklarından siyrılarak kendisine parlak bir politik prestij kazandırmasını beklediği Milletler Cemiyeti'nin kurulması için tüm zamanını harcadı. Özellikle böyle bir teşkilatın kurulması öngörüsünün Versailles anlaşmasının metnine dahil edilmesi Wilson'un en sı̆̆ duygularını kabartmaya yetmişti. ${ }^{2}$

Wilson'un Milletler Cemiyeti'nin kurulmasıyla bu kadar yakından ilgilenmesinin sebepleri Amerikan tarihçileri arasında farklı şekillerde yorumlanmıştır. Bir görüşe göre Başkan'ın duygusallığı ve bu duygusallı̆̆g daha da güçlendiren trajik politik hadiseler, Wilson'un böyle bir çaba içerisinde olmasının başlıca sebebiydi. Başkan iyi bir Hıristiyan olarak dini idealler ve öğretilere gönülden bağlı idi. Dolayısıyla bu idealleri ve öğretileri politik hayata taşımaya çalışmıştır. Wilson'un bir tarihçi olması hiç kuşkusuz onun politik romantizmini arttıran bir başka sebep olarak sayılmalıdır. Başkan bu idealine o kadar büyük bir ruhla bağlı idi ki, Amerikan parlamentosuna Ağustos ayı içerisinde gönderdiği bir mektubunda konunun kendisine yüklediği manevi sorumluluğun gün be gün artarak dayanılmaz boyutlara ulaştığını yazmışıı. ${ }^{3}$

Robert Goldsmith 1917'de yazdığı bir kitapta I. Dünya Savaşının ortaya çıkışının başta Hıristiyanlık olmak üzere büyük dinlerin toplum ve siyaset alnında etkisiz kalışının bir kanıtı olduğu görüşünü savunmuştur. Bütün dinlerin yeryüzünde barıșı hakim kılmayı amaçladı̆̆ını ve Hz. İsa'nın savaşan bir dünyaya karşı olmak için gönderildiğini yazan Goldsmith, materyalistlerin fiziki güce ihtiyaçlarının olduğunu ve bu gücü kazanmak için milyonları ölümün eşiğine sürüklemekten çekinmeyeceklerini açıklayarak; ancak dini itikat'ın güçlülüğü ve insanın maddeye değil de kendinden daha güçlü olan ulvi bir varlığa bağglılığ kendisine her türlü güçten daha yüksek bir güç sağlayacağını belirtmiștir. Yazar barıșı korumak için ise bir uluslararası bir dayanışma ve bir birliğin oluşturulmasını

${ }^{2}$ Boyer, Clark, Kett, Salisbury, Sitkoff, Woloch, The Enduring Vision, Heath and Company, Lexington, 1993, s. 791.

${ }^{3}$ Schulte-Nordhold, Jan W. 'The Peace Advocate Out of Touch With Reality' Major Problems in American Foreign Relations Since 1914, Massachusetts, 1995, s. 53. 
istemiştir. ${ }^{4}$ Goldsmith'in düşünceleri Wilson'un da paylaştığı o zamanki dini romantizmi ve idealizmi ifade etmesi açısından önem taşımaktadır.

Başkan'ın Milletler Cemiyeti fikrinin politik gereklilikten doğduğunu ve barışın Amerikan milli çıkarlarına hizmet edeceğini düşünen tarihçiler ise Wilson'u bir idealist olmaktan ziyade gerçek bir realist olarak tanıtmaktadırlar. Arthur S. Link, Başkanın idealist ve realist yapısına ilginç bir eşitleme getirmektedir. Link'e göre Wilson'un hayatını inceleyen araştırmacıların Wilson'un öncelikli olarak bir Hıristiyan idealisti olduğu gerçeğini mutlaka tespit edeceklerdir. Wilson kararlarını stratejik veya maddi kazançlardan ziyade, Hıristiyanlık standartlarına uygun olup olmadığına göre vermiş ve Başkan Hıristiyanlık kaidelerini ferdi boyutlarda olduğu gibi uluslararası platformlarda da geçerli kılmak istemiştir. Ancak Link'e göre Wilson'un taraf olduğu ve mücadelesini verdiği fikirler aslında kendi nesli için oldukça geniş anlamlar ve en yüksek realist politikaları ihtiva ediyordu. Bu anlayış çerçevesinde her ne kadar Wilson idealist olsa da kazandırmak istediği politikalar ileri görüşlü realist düşünceler idi. ${ }^{5}$

Wilson savaş karşıtı idi çünkü savaş kazanılsa bile büyük kayıplara yol açma riski taşıyordu. Ancak savaşlar büyük güçlerin kendi çıkarlarını korumak için vazgeçilmez bir enstrüman idi. Oysa ki, Wilson'un Amerika'sı büyük güç rolüne aday değildi ve bu şartlar altında ülkenin savaşlardan kazanc sağlayacak bir durumu yoktu. Ancak Amerika Birleşik Devletleri önemli bir siyasi ve ekonomik güce erișmiș ve geleceğin dünyasında etkin bir rol alacağı Avrupa güçleri tarafından kabul edilen bir gerçekti. Wilson 14 Nokta prensipleriyle ortaya konulan 'yeni diplomasi ${ }^{\prime 6}$ kuramıyla savaştan elde edemediği toprak ve materyal kazançlara diplomatik yollarla ulaşmayı hedefliyordu. Özellikle Ortadoğu ve Çin gibi bölgelerde örtülü bir emperyalist mücadele sürdüren Amerika, Wilson ilkeleri ve özellikle uluslara self-determinasyon hakkı tanıyan 12. madde ile bu bölgelerde Avrupa devletleri ile olan rekabette çıkar sağlamayı amaçlıyordu. Aslında başkan Wilson ve Wilson ilkelerinin baş mimarı ünlü strateji uzmanı Walter Lippmann 12. madde ile sömürge ve işgal altındaki milletlere hemen özgürlük öngörmüyordu. 12. maddeye dayanarak, Milli Mücadele içerisindeki Türkiye'den gelen diplomatik yardım çağrılarını Wilson'un cevapsız bırakması ve Versailles'de Wilson'u milli bağsızlık için en büyük umut olarak gören, sonradan kuzey Vietnam'ın lideri olarak Amerika'ya karşı savaşacak olan Ho Chi Minh ve diğer sömürge ülkeleri temsilcilerinin görüşme taleplerinin de Wilson tarafından geri çevrilmesi bu gerçeğe işaret etmektedir. Wilson'un kendi koyduğu 12. maddeye karşın bağımsızlıklarını 1917.

${ }^{4}$ Robert Goldsmith, A League to Enforce Peace, The Macmillan Company, New York,

5 Arthur Link, 'Wilson's Higher Realism' Major Problems in American Foreign Relations, ss. 47-48.

${ }^{6}$ Robert D. Schulzinger, American Diplomacy in the Twentieth Century, Oxford University Pres, New York, Oxford, 1994, s. 88. 
düşleyen milletlere karşı en ufak bir ilgi duymaması Wilson ilkelerinin kelime anlamından daha gizli amaçlar ifade ettiği gerçeğini ortaya koyuyordu.

Savaş yerine ekonomi ile ilgili politikalar Amerika'nın daha fazla ilgi duyduğu konulardı. Daha fazla ticaret ve daha fazla ihracat Amerikan menfaatlerine en fazla katkıda bulunacak politikalardı. O yüzden Wilson'un çoğu kez hissi ve dini duyarlılıktan kaynaklandığı sanılan politikaları aslında Amerika'nın ihtiyaçlarına cevap verecek liberal ve realist bir karakter taşıyordu. Amerikan ticari rekabetini güçlendirmek için Amerika Avrupa'ya mal satmalı ve ham madde kaynaklarını Avrupalı sömürgecilerin tekelinden kurtarmalıydı. Bu politikalar zaten Amerika'nın 19.yy sonlarından itibaren 'open door policy' ismi altında takip ettiği temel dış politikası idi.

Başkan Wilson politikalarını üretirken, Amerikan dış politikalarının neredeyse bir yüzyıldır temel ve değişmez unsuru olan 'Monroe Doktrini'nin gerekçelerinden ayrılmadığını özelikle vurgulamış ve Monroe Doktrini'ni gerçek manasıyla yorumladığını ileri sürmüştür. Amerika Birleşik Devletleri, genç bir devlet olarak, gerek Avrupa baskısından kurtulmak ve gerekse kendi bölgesinde etkin olan Avrupalı emperyalistlerin nüfuzlarını kırma için, Amerikan idealleri olarak adlandırılan ve emperyalizm karşıtı demokratik bir uluslararası sistemi öngören bir anlayış içerisinde, 1823 senesinde Monroe Doktrini'ni ilan etmiştir. Bu Doktrine göre ABD Avrupa'nın siyasal çekişmelerinden uzak duracak ve Avrupa devletlerinin Amerika kıtasındaki emperyalist politikaları engellenecekti. Monroe Doktrini söylem olarak bir şemsiye gibiydi ve altında farklı anlayışları ve uygulamaları barındırıyordu. Özgürlüklerden bahseden ve emperyalizm karşıtı olduğunu iddia eden Amerika'da devam eden kölelik düzeni Amerika'nın öngördüğü dünya düzeniyle taban tabana zıttı. Kaldı ki Amerikan başkanı Theodore Roosevelt kendisini bir emperyalist olarak nitelendirmekten çekinmiyordu? Amerika'nın 1893'te Venezüella üzeride sürdürdüğü mücadele, 1897'de Hawaii adalarını ilhakı ve 1898 'de İspanya'ya karşı yürüttüğü ve sonucunda kendisine Puerto Rico, Küba ve Filipinlerin kontrolünü ele geçirme firsatı sağlayan 'küçük ve parlak savaş' Monroe Doktrini'nin ruhuyla taban tabana zit emperyalist harekelerdi. Bu gerçekten hareketle, başkan Wilson'da Monroe Doktrini'ne başka anlamlar izafe ederek, Amerikan idealleri çerçevesinde yeni politik açılımlara dünya politikalarında yer bulmaya çalışmıştır.

Wilson'un aklındaki yönlendirici sebep her ne olursa olsun, Paris Konferansında elde ettiği başarı onun şartlarındaki bir lider için azımsanmaması gereken bir zaferdi. Wilson'un başarısında Avrupa'nın şartları ve Avrupa'nın Amerika'ya olan ihtiyacı ve Amerika'dan beklentilerinin payı göz ardı edilmeyecek kadar mühimdir.

\footnotetext{
${ }^{7}$ Schulzinger, s. 5 .
} 
Versailles toplantılarında Milletler Cemiyeti fikrini formüle edip bunu Avrupalılara kabul ettirmeye çalışan Başkan Wilson muhatabı olduğu Avrupalı liderlere göre dünya politikalarında oldukça tecrübesizdi. Hatta toplantılara iştirak eden Çek lider Thomas Masaryk bile Wilson'un kurtlar sonrasında olduğunu ve Avrupalı liderlere dikkat etmesi gerektiğini söylemiştir. Wilson'un düşük kredisi ve zayıf politik zekasına rağmen savunduğu fikirlere bütün gönlü ve ruhuyla inanması onu görüşmelerde etkin kılmıştır. Fransız lider Clemenceau yaptı̆̆ 1 bir konuşmasında kendisinin Wilson'un savunduğu fikirleri paylaşmamasına rağmen, onun 'asil içtenliğini’ büyük bir saygıyla takdir ettiğini söylemiştir. ${ }^{8}$

Aslında Avrupalı liderler Wilson'dan ve onun amatör tavırlarından hoşlanmıyorlardı. Başından beri bu liderlerle Wilson arasında hissedilir bir gerilim vardı. Özellikle tecrübeli politikacı Clemenceau Wilson'un parlak sözlerinden etkilenecek gibi görünmüyordu. Clemenceau Amerikan idealleri ve Wilson'un 14 nokta prensipleriyle dalga geçiyordu. Clemenceau tanrının bile sadece 10 emri olmasına rağmen Wilson'un 14 prensibinin olduğunu söyleyerek, Wilson'un savunduğu fikirleri hafife alıyordu. Clemenceau Wilson'u iğnelemeye devam ederek, Wilson'un konuşurken $\mathrm{Hz}$. İsa gibi konuştuğunu ancak Lloyd George gibi hareket ettiğini söylemiştir. Clemenceau'nın tavrı Amerika'da da yankı uyandırmıs ve hatta Fransız liderin sözleri Wilson'un siyasi rakibi Roosevelt tarafından takdir edilmiştir. Roosevelt, biraz da Wilson'a yüklendiği için, Clemanceau'ya olan hayranlığını ona yazdığı mektuptaki 'aman efendim sizin Amerikan başkanı olmanızı nasıl isterdim' sözleriyle yükssek bir perdeden dile getirmiştir.'

Müzakerelerde diğer liderler ara verip konferans salonunu terk etmelerine rağmen, Wilson çalışmalarına hiç ara vermeden günler ve haftalar boyu süren sıkı bir çalışma temposuna girdi. Wilson daha sıkı ve daha uzun çalıştıkça müzakerelerde daha baskıcı ve karşı fikirlere hiç tahammül edemeyen bir yapıya bürünerek, Avrupa liderleriyle olan ilişkisinde mesafe ve kırılganlık yarattı. ${ }^{10}$

Bütün kişisel olumsuzluklarına rağmen, Wilson Milletler Cemiyeti fikrinin bütün sıkıntılara karşı mucizevi bir şifa kaynağı olduğunu ve bunun barış anlaşmasının kendisiyle de ayrılmaz bir doğallığının bulunduğunu savunmuş ve savunduğu bu fikirleri Avrupalı liderlere kabul ettirmiştir. Nisan 1918'de Wilson yapılacak barış anlaşmanın mükemmel olmayabileceğini ancak Milletler Cemiyeti'nin şekillenmekte olan anlaşma mekanizmasının hareket kabiliyetini arttıran bir entegre işlevi göreceğini belirtmiştir. ${ }^{11}$

\footnotetext{
${ }^{8}$ Schulte-Nordholt, s. 59.

${ }^{9}$ Schulte-Nordholt, s. 60 .

${ }^{10}$ George Scott, The Rise and Fall of the League of the Nations, Macmillan Publishing, New York, 1974, ss. 39-40.

"Schulte-Nordholt, s. 60.
} 
Uzun tartışmalar sonucu Milletler Cemiyeti kanunnamesi şekillendi ve Paris Konferansı'na katılan devletler tarafından kabul edildi. Milletler Cemiyeti tüzüğü 26 maddeden oluşmaktaydı. Onuncu madde üye şartlarını ve sorumluluklarını düzenlemesi bakımından teşkilatın en önemli maddesi olarak ön plana çıkmıştır. Onuncu maddeye göre Milletler Cemiyeti'ne üye ülkeler diğer üye ülkelerin bağımsızlığına ve toprak bütünlüğüne karşı tehdit oluşturamazlardı. Böyle bir tehlikenin ortaya çıkması halinde Milletler Cemiyeti Konseyi'nin onuncu maddeden doğan yükümlülüklerinin yerine getirilmesi için taraflara tavsiyelerde bulunmak yetkisi vard1. ${ }^{12}$

Milletler cemiyeti fikri daha ziyade Avrupa devletlerine hitap ediyordu. Çünkü, dünyada karıșıklıklara yol açan büyük devletler Avrupa devletleriydi. Onların anlaşmaları ve barışı koruma çabaları şüphesiz dünya barışı için çok etkili olacaktı. Savaştan yeni çıkmış Avrupa ülkeleri birer birer Milletler Cemiyeti anlaşmasını imzaladılar. Savaş sonrası İngiltere'sinde İşçi Partisi ve bu partinin destekçileri kuvvetli bir uluslararası organizasyonun dünya barışı için çok önemli olduğunu düşünüyor ve böyle bir çabayı dış politikalarında en merkezi yere oturtuyorlardı. İngiliz hükümeti savaşları engelleyecek bir uluslararası mekanizmanın kurulması amaciyla Milletler Cemiyetini destekliyordu. Bu duygunun yanı sıra İngiliz hükümeti bu anlaşmayı onaylayarak onun savunucusu Wilson'a yakın olabileceklerini ve dolayısıyla yükselen güç ekseni Amerika Birleşik Devletleri'ne yakın durarak ve onun dostluğunu kazanarak politik bir çıkar elde etmeyi planlıyordu. ${ }^{13}$

Sonuçta İngiltere 1919'da Avam Kamarasında Milletler Cemiyeti sözleşmesini bütün Versailles anlaşması hükümleri ile birlikte sadece iki gün tartıştıktan sonra kabul etti ve bu sözleşmenin gerektirdiği bütün şartlara uyacağını açıkladı. İngiltere bu sözleşmeyi onaylarken Amerika'nın da hiç şüphesiz aynı şeyi yapacağını hesaplamıştı. ${ }^{14}$

Avrupa'da Milletler Cemiyeti'nin kurulmasına Almanya'dan sürpriz bir destek geldi. 1918-1919 yılları arasında Almanya barış müzakerelerinde bulunurken Wilson'un milletler topluluğu fikrine heyecanla yaklaşmıştır. Alman halkı da tıpkı hükümetleri gibi barış ve daha iyi yaşam şartları oluşturmak inancıyla, hür ve eşit milletlerin savaş sonrası adil bir barış için birleşmeleri fikrini kuvvetle destekledi ve Milletler Cemiyeti'ne katılmak için büyük bir çaba sarf etti. Ancak Almanya'nın bu beklenmedik kararlılığı

${ }^{12}$ Alfred Zimmern, The League of Nations and the Rule of Law 1918-1935, Macmillan Publishing, London, 1936, s. 501.

${ }^{13}$ Henry R. Winkler, The League of Nations Movement in Great Britain 1914-1919, Scareckow Reprint, Metuchen, 1967, ss. 259-261.

${ }^{14}$ Zimmern, s. 302 
Almanya'yı farklı bir statüde tutmak isteyen savaşı kazanan güçler arasında rahatsızlık yarattı. ${ }^{15}$

Milletler Cemiyeti'nin oluşumuna Avrupa'nın savaşta tarafsız kalmış ülkeleri de katıldı. Aralık 1918 'de üç İskandinav ülkesi; Danimarka, Norveç ve İsveç görüşmelere ev sahipliği yapan Fransa'ya nota vererek Milletler Cemiyeti'nin kuruluş çalışmalarının bütün ülkelere açık olması gerektiğini savundular. Bunun üzerine bu üç tarafsız ülkenin temsilcileri Hotel Crillon'daki özel müzakerelere katılmaya davet edildiler. ${ }^{16}$

Wilson'un savaş zamanlarından beri savunduğu uluslararası ilkeler kozmik ışık gibi Avrupa ve dünyanın diğer bölgelerine yayılıyordu. Avrupa'da yeni devletler kuruluyor ve bu devletler topraklarını ve bağımsızlıklarını korumak için Milletler Cemiyeti fikrine umutla sarılıyorlardı. Avrupa'nın büyük devletleri ise uluslararası barışı tesis ederek kendi iç meseleleriyle uğraşıp, savaşın yaralarını sarmayı düşünüyorlardı. Artık benzer davranışları gösterme sırası Amerika'ya gelmişti. Avrupa'nın destek verdiği ve Wilson'un en büyük savunucusu olduğu, barışı korumak için milletlerin bir araya gelmeleri fikrine doğal olarak Amerikan politikacıları ve Amerikan halkının büyük bir destek vermesi bekleniyordu. Ancak beklentiler yerini bulmadı ve Wilson'un idealleri kendi ülkesinde gerekli ilgiyi uyandırmadı.

\section{Wilson'un Evde Uymayan Hesabı}

Wilson Amerikan iç savaşından sonra göreve gelen ikinci Demokratik Parti lideri idi. 1916 'da seçilmesi büyük oranda rakibi Roosevelt' in yaptığı politik hatalara bağlıyd. ${ }^{17}$ Bu yüzden Wilson kredisi yüksek bir Amerikan başkanı değildi ancak 'Wilson ruhu' diye adlandırılan politik bir akımın öncülüğünü yapacak kadar da Amerikan politikalarında iz bırakmıştır. Wilson'un başkanlığı zıt gelişmeleri de beraberinde getirmiştir. Eğer Wilson başkan olmasaydı büyük bir ihtimalle Milletler Cemiyeti kurulamayacaktı, ancak, Wilson'un başkan olması, diğer taraftan, Amerikan parlamentosunun Versailles anlaşmasını onaylamaması ve Milletler Cemiyeti'ne katılmamak yönünde karar vermesinin de en önemli sebebi olmuştur. ${ }^{18}$

Temmuz 1919'da Paris'ten ülkesine dönen Wilson, Paris konferansı sona erdikten sonra, artık Avrupalı liderler tarafından da kurulması desteklenen bu uluslararası organizasyonun Amerikan politikacıları ve halkı tarafından da kabulü için çalıştı. Wilson yaptığı konuşmaların bir çoğunda

${ }^{15}$ Christoph M. Kimmich, Germany and the League of Nations, The University of Chicago Press, 1976, s. 194.

${ }^{16}$ Shepard S. Jones, The Scandinavian States and the League of Nations, Greenwood Press, New York, 1969, ss. 47-49.

${ }^{17}$ Thomas J. Knock, 'Wilson's Battle for the League: Progressive Internationalistics Confront the Forces of Reaction' Major Problems in American Foreign Relations, s. 67.

${ }^{18}$ Scott, ss. 38-39. 
Milletler Cemiyeti'nin kurulmasının öneminden bahsetti. Wilson 27 Eylül 1918 'de New York'taki Metropolitan Opera Evi'nde yaptı̆̆ 1 bir konuşmada Milletler Cemiyetinin gerekliliğini, Amerika'nın tavrını halkına şu sözlerle ifade etti:

\begin{abstract}
Modern dünyadaki siyasi kutuplaşmalar ve ekonomik çıkar düşmanlıkları savaşları üreten ve körükleyen asıl ve gitgide yaygınlaşan sebeplerdir. Bu yarışı ve düşmanlıkları kesin olarak engellemeyen barış hükümleri gerçekçi ve yürütülebilir olmayacaktır. Kendi halkımıza anlatmaya çalıştı̆̆ım bu konular ne bizim Amerikan geleneklerinden ne de ülkemizin takip ettĭgi ve herkes tarafindan çok iyi bilinen uluslararası prensiplerinden kaynaklanmaktadtr. Bu cümleden olmak üzere şunu belirtmek isterim ki, Birleşik Devletler belli milletlerle bazı özel politik angajmanlar ve uyumlar içerisine kesinlikle girmeyecektir. Şunu da belirtmeme müsaade edin; Birleşik Devletler güvenli bir barışın tesis edileceği genel anlaşmalar ve yükümlülüklerde kendi payına düşen bütün sorumluluğu mutlaka yerine getirecektir. Biz. Washington'un ittifak yumaklarına karşı inançlı uyarılarımızı, ittifaklara karşı kendi anlayışımız ve cevabımız. olarak devam ettireceğiz. Birleşik Devletler sadece bize yeni bir gün vadeden ve bize bütün ittifaklarl ortadan kaldırma umudu verecek, dünyanın havasını genel anlayış ve genel hakların kabulü çerçevesinde değiştirerek genel bir ittifak kurmaya izin verecek özel ve sınırlı bir ittifakı tanıyabilir. ${ }^{19}$
\end{abstract}

Wilson muhtaç olduğu desteği seçilmişlerden ve halktan alabileceği konusunda ciddi şüpheleri vardı. Şubat ayında kısa bir süre için Paris’teki müzakerelerden ayrılarak ülkesini ziyaret eden başkan, Milletler Cemiyeti'nin kurulması fikrine karşı gerek Amerikan kongresinde ve gerekse kamuoyunda gelişen olumsuz havayı müşahade etmişti. Wilson'un önündeki en büyük engel, Amerika'nın Milletler Cemiyeti işine bulaşmasından memnun olmayan, muhalefeti kanalize eden ve yöneten, kelimenin tam anlamıyla Wilson'un bir numaralı politik düşmanı bir senatör idi. Bu politikacı Senato Dış İlişkiler Komitesi başkanlığı gibi önemli bir mevkide bulunan Senator Henry Cabot Lodge idi. ${ }^{20}$ Senato Dış İlişkiler Komitesi başkanı senatoda çoğunluğu olan parti veya ağırlığı olan siyasi eğilim temsilcilerinden seçilmekteydi. Amerikan başkanlarının senatodaki nüfuzlarının zayıflığı Amerikan siyasi tarihinde sıkça rastlanan bir durumdur. Wilson'un başkanlığı sırasında da Wilson'a muhalif gruplar Senato'da söz sahibi idiler. Yine bir çok Amerikan başkanının dışişleri ile ilgili siyaset üretirlerken en çok korktukları Senato Dış İlişkiler Komisyonu'ndan Wilson da çekinmiştir. Çünkü, bu komisyon hükümetin dışişleriyle ilgili hazırladığı tasarıları görüşüp, gerekli gördüğü değişiklikleri

\footnotetext{
${ }^{19}$ Edith M. Phels, A League of Nations, The H. W. Wilson Company, New York, 1918.

${ }^{20}$ Scott, s. 41 .
} 
yaparak Senato'ya gönderiyordu. Komisyon'un lehte veya aleyhteki tutumunun herhangi bir tasarının Senato'dan geçip geçmemesi konusunda önemli bir etkisi vardı. Bu yüzden Wilson bir yolunu bulup karşıt görüşteki Lodge engelini aşmalıydı.

Wilson bir yandan Senato'daki olumsuz havayı gidermeye çalışırken diğer yandan halkı ikna turlarına çıktı. Başkan Wilson 3 Eylül'de ülkenin batısına bir tura çıtı. Yirmi iki gün süren seyahatinde başkan dokuz bin milden fazla bir yolu trenle kat etti, geniş ve coşkulu kalabalıklara otuz yedi mitingle seslendi. ${ }^{21}$

Wilson halka Milletler Cemiyeti'ni anlattı ve böyle bir projenin insanlık tarihinde nasıl bir dönüm noktası olacağını parlak sözlerle ifade etti. Wilson konuşmalarında böyle bir projenin kabulünün dünyanın Amerikanın dış politika ilkelerini kabulü anlamına geleceğini vurguladı. 17 Eylül'de San Francisco, California'da yaptığı konuşmasındaki 'uluslararası diplomaside ilk kez bir büyük millet Monroe Doktrini'nin geçerliliğini kabul etmiştir. Ve şimdi yine ilk defa, zaman içerisinde büyük savaşçı devlet olma vasfından uzaklaşmış olan Almanya hariç, bütün büyük savaşçı devletler Monroe Doktrini'nin geçerliliğini kabul etmiş ve onu dünyadaki uluslararası uygulamaların bir parçası olarak tanımışlardır' sözleriyle Amerikan politikalarının nasıl dünyaya mal edildiğini izah etmeye çalışmıştır. ${ }^{22}$

Amerikalı araştırmacılar Amerikan dış ilişkileri idealizminde Amerika'nın politika olarak her zaman güçlünün karşısında zayıfı korumak eğiliminin olduğunu savunmuşlardır. ${ }^{23} \mathrm{O}$ zamanki Amerika'nın konumundan dolayı, iyi niyet yahut çıkarları gereği olduğu tartışmalı olmakla beraber, sömürgeciliğe karşı aldığı tavır buna örnek olarak gösterilmiştir. Amerika'nın kendisini dünya politikalarından izole etmesiyle açıklanan Monroe Doktrini, Wilson'un kastettiği haliyle başka anlamlar ifade ediyordu. Wilson'a göre Monroe Doktrini uluslararası ilişkilerde devletlerin eşitliğini ve zayıf olanın haklarının korunması ilkelerini öngörüyordu. İşte Milletler Cemiyeti Amerika'nın doktrin haline getirmiş olduğu bu kuralı dünya ülkelerine kabul ettirecekti. İşin bu yönüyle Wilson Monroe Doktrini'nde ifadesini bulan geleneksel ve içe kapanık Amerikan dış politikasının değiştirilmeye çalışıldığı yönünde gelecek tenkitleri doktrinin farklı açılımlarını kullanarak kaynağında önlemeye çalışmıştır.

Wilson konuşmalarında Amerika'nın savuna geldiği serbest ticaret ve dünya kaynaklarının kullanımının sömürgeci güçlerin tekelinden kurtarılmasının önemine de değinmiştir. Ekonomik kaynakları elinde bulunduran ülkelerin bu kaynaklara sahip olmayan ülkeleri nasıl bertaraf

\footnotetext{
${ }^{21}$ Enduring Vision, s. 792.

${ }^{22}$ Merrill, Paterson, s. 45.

${ }^{23}$ Samuel Mc Cune Lindsay, The League of Nations Covenant, Columbia University Press, New York 1919, s. 41.
} 
ettiklerini Almanya'nın yenilgisiyle örneklendiren Wilson, Amerikan ekonomisinin de kuvvetle ihtiyaç duyduğu ham madde kaynaklarına ulaşma çabalarında ülkenin Milletler Cemiyeti perspektifinde gelişen yeni dünya düzeniyle başarı sağlanacağını halkına anlatmaya çalışmıştır. Wilson 4 Eylül'de Indianapolis, Indiana'da yaptığı bir konuşmada Almanya'nın başına gelenlerin önlem alınmasa Amerika'nın da başına gelebileceğini hissettirerek 'bu savaşın sadece ordular tarafından değil bundan daha önemli olarak ekonomiler tarafından kazanıldığını ifade etmek istiyorum. Eğer böyle olmasaydı savaş daha uzun bir süre devam edebilirdi. Almanya'nın başına gelen şey bu ülkenin bütün dünyadaki ekonomik kaynaklardan mahrum edilmesi ve ülkenin ekonomik sebeplerle ayakta duramamasıdır' demiştir. ${ }^{24}$

Wilson Milletler Cemiyeti'ni halkına anlatmak için ülke turuna çıktığı bir dönemde, 10 Eylül 1919 tarihinde, Dış İlişkiler Komite'si Versailles Barış Anlaşması'nı ve Milletler Cemiyeti sözleşmesini görüşerek ve üzerinde önemli değişikliklerin yapılmasını öneren bir rapor beraberinde Senato'ya gönderdi. Raporda yapılması istenen değişiklikler senatör Lodge tarafından oldukça kendini beğenmiş bir tonda ifade edildi. Rapor anlaşmanın ve sözleşmenin kabulü için çok sayıda değişiklikler ve çekinceler önermiştir. Senato, ancak, büyük bir çoğunlukla raporda belirtilen değişiklik isteklerini reddetmiştir.

Aslında Lodge'nin ana stratejisi zaten bu değişiklikleri kabul ettirmek değildi. Senator Lodge esasında çekinceleri gündemde tutmak istiyordu. Lodge değişiklikleri reddeden Senato'ya Versailles anlaşmasını ve Milletler Cemiyeti sözleşmesini daha ziyade sözleşme üzerinde belirlenmiş on dört çekince ile birlikte kabul edilmesi yönünde bir uzlaşma teklifinde bulunmuştur. Başkan Wilson kendisini destekleyen senatörlerden Lodge'nin sunduğu tezkerenin Senato'dan geçirilmemesini istemiştir. Tarihi oylama 19 Kasım 1919'da gerçekleştirilmiş ve sonuçta her tür sözleşmeye karşı olanlar ile sözleşmeyi çekincesiz kabul etmek isteyen senatörlerin olumsuz oyları sonucu tezkere reddedilmiştir. ${ }^{25}$

Senato'daki tartışmalarda Milletler Cemiyeti kuruluş nizamnamesinin onuncu maddesi en fazla gündemi işgal eden konu olmuştur. Cabot Lodge onuncu maddeyi Amerika'nın Milletler Cemiyeti'nin bir polis gücü olarak evlatlarını dünyanın sorun içerisindeki bütün bölgelerine göndermesinin şartı şeklinde yorumlamıştır. ${ }^{26}$ Wilson'un Monroe Doktrini'ni hümanist bir gözle yorumlayarak, doktrinin zayıf milletlerin haklarını koruma amacı taşıdığı fikrine senatörlerin bir çoğu katılmamış olmalı ki, onlar Amerika'nın hiç bir ülkenin toprak bütünlüğünü ve politik bağımsızlığını korumak için

\footnotetext{
${ }^{24}$ Merrill, Paterson, s. 41.

${ }^{25}$ F. P. Walters, A Story of the League of Nations, Oxford University Press, 1965, ss. 70-75.

${ }^{26}$ Scott, s. 43.
} 
yükümlülük altına giremeyeceğini beyan etmişlerdir. Sözleşmeyi Amerikan senatosunda en sevimsiz yapan bu onuncu madde ve maddenin getirdiği sorumluluklar olmuştur.

Wilson'un Senato'ya gönderdiği Milletler Cemiyeti sözleşmesi, Senato'da yapılan iki oylamada da geçmedi. Bunun üzerine çoğunluk liderleri ortak hareket ederek konunun bir sonuca bağlanmasını teklif etti ve bu karar Senato'dan geçti ancak bu sefer de Senato'dan geçen karar Wilson'un vetosuna takıldı. ${ }^{27}$ Böylece konu ile ilgili karar süreci tam bir çıkmaza girdi. Başkan Wilson inatçı bir tavırla sorunun aşılması ve bir sonuca bağlanması için yapılan bütün pazarlıklara kulağını tıkadı. Bu amaçla kendisine iletilen her fikre kestirmeden 'uzlașma yok' cevabını verdi. Wilson'un sağlığının bozulması konunun rafa kaldırılmasına sebep oldu. Başkan Wilson'un, iki kez Tromboz geçirmesi sonucu, sol tarafına felç indi. Zaten başkanlığının da sonuna gelmiş olan Wilson artık daha ziyade ciddi sağlık sorunlarıyla ilgilenmekteydi.

1920'deki seçimleri Cumhuriyetçi Parti adayı Warren Harding kazandı. Yeni bașkan içten içe Milletler Cemiyeti'nin gerekliliğine inansa da Demokrat başkan Wilson'la özdeşleşmiş olan bu teşkilatın Amerika tarafından kabul edilmesine politik sebeplerden dolayı karşı çıkmıştır. Harding bu kararını açıklarken, Amerika'nın dünyadaki sorunların içine çekilmesinin doğru olmayacağını gerekçe olarak göstermiştir. ${ }^{28}$

\section{SONUÇ}

Wilson'un Paris'te Avrupa liderlerine sarsılmaz inancı ve direnci sayesinde kabul ettirdiği Milletler Cemiyeti'ni bütün enerjisini ortaya koymasına rağmen kendi ülkesinde kabul ettirememesi beklenmedik bir gelişme olarak dünyayı şaşırtmıştır. Wilson her ne kadar Amerikan politik gelenek ve ideallerinin Milletler Cemiyeti vasitasıyla dünyaya kabul ettirilmiş olduğu tezini başarıyla formüle etmiş olsa da, Amerikan halkı ve özellikle de Amerikan politikacıları Wilson'un hararetle anlattıklarına pekte katılmamışlardır. Her şeyden önce Amerikan halkı Wilson'un savunduğu uluslararası misyonu yerine getirecek bilinç ve oryantasyondan uzaktı. Wilson'un fikirleri halk ve politikacılar tarafından Amerika hiç gereği ve ihtiyacı yokken elini taşın altına sokuyor ve ülke karmaşık dünya sorunlarının içine sürükleniyor diye algılandı.

Wilson'un temsil ettiği romantizminden sıyrılıp böyle bir teşkilatın kurulmasının, özellikle de Avrupa'nın büyük devletlerinin Amerika'ya dünya siyasetinde büyük güç olma imkanını vermeyi kabul ettikleri bir

${ }^{27}$ D. F. Fleming, The United States and the League of Nations 1918-1920, Russell \& Russell, New York, 1968, s. 451

${ }^{28} \mathrm{~S}$ cott, s. 47. 
zamanda, Amerika'ya sağlayacağı faydaları hesap eden Amerikan politikacıları mutlaka vardı. Ancak bu organizasyonun Amerika tarafından kabul edilmesi Wilson'un daha ziyade kişisel meselesi olarak görülmesi ve Wilson'la onun siyasi rakipleri arasında kıran kırana bir mücadeleye sebep vermesi ve bütün bunlara Wilson'un uzlaşmaz tavrı da eklenince, konu bu mecralarda boğularak Milletler Cemiyeti'nin Amerikan menfaatlerine yapacağı katkılar fazlaca tartışılamamıştı. Böylece Wilson'un 'asil idealleri' onun 'asil trajedisi'ne dönüşmüş ve Wilson çok başarısız liderlerin alabileceği türden ağır bir yenilgiye uğramıştır. II Dünya Savaşı sonrası yeni dünya düzenini kavramaya ve bu düzende Amerika'nın alacağı rolü belirlemeye çalışan Amerikan yönetiminin ilk işlerinden birisi Wilson'un fikirlerini tekrardan değerlendirmek olmuştur. Adeta yeni Wilsonculuk felsefesiyle Amerika Birleşmiş Milletler ve diğer uluslararası organizasyonlarda temel unsur olarak yer almış, dünya siyasetinde liderliğe oynamış ve bu politikalar sonucu hegemon güç haline gelmiştir. 